\title{
DIVIDING WORLDS
}

\author{
Tsunamis, Seawalls, and Ontological Politics \\ in Northeast Japan
}

Andrew Littlejohn

\begin{abstract}
In 2011, a tsunami devastated Japan's Northeast coastline following a magnitude 9.1 earthquake. In its aftermath, disaster scientists, civil engineers, and central government officials advocated protecting people and property from future oceanic incursions by armoring the coast with giant seawalls. Many survivors challenged this recommendation, arguing for other ways of ensuring safety and organizing humannonhuman relations across the land-water interface. This article analyzes such resistance as acts of what I call 'ontological dissensus': the lodging of alternative ways of attuning to, conceptualizing capacities of, and arranging relations between beings in one's environment into dominant ones. I argue that such a theory helps us not only to understand antiseawall activism in post-tsunami Japan, but also to consider how, and when, ontological difference becomes active in political controversies.
\end{abstract}

Keywords: disaster, Jacques Rancière, Japan, ontology, political theory, seawalls, 3.11

At 2:46 PM on 11 March 2011 (known as 3.11), part of the Pacific Plate was forced under the Okhotsk Plate off Japan's Northeast coastline, resulting in an undersea megathrust earthquake with a magnitude of 9.1. People perceived the ground shaking as far away as Beijing. But one person on the Northeast's Sanriku Coast did not feel it tremor. Sanriku is a seaboard characterized by innumerable small, riverine valleys descending from a mountainous interior. A little over an hour before the earthquake, in a small town called Minamisanriku a diver entered the sea near one of these valleys' mouths. He was going to mend aquaculture racks in the bay, which fishermen used to cultivate oysters and scallops in the plankton-rich waters. At first everything seemed normal. As he 
worked, however, he began to notice changes in the ocean around him. Something red as blood was staining the water. The fish that normally accompanied him had vanished. Concerned, he stopped working and headed back to shore (Akasaka et al. 2011: 116). Shortly after he reached land, a tsunami arrived.

When the ground shook, many residents anticipating the wave fled immediately to higher ground. But some, believing seawalls guarding the dales would protect them, remained in or returned to their houses. Unable to see the ocean, they realized too late that the tsunami had breached these defenses. One woman, who fled at the last possible minute, explained to me: "I had returned to the house ... I didn't think the tsunami could reach it, you see. And I stayed the whole time on the ground floor. Then, when an old man nearby said, 'Run, a tsunami is coming,' I fled. But by that time the tsunami had already arrived. I was downstairs, so I didn't know ... I couldn't see it."

Some in her situation tried to evacuate by car; others made hurriedly for the valley sides, or climbed on their house's roofs. She escaped by the skin of her teeth, reaching the mountainside bordering her hamlet's valley just ahead of the water. But many others late to flee were not so fortunate. Almost 22,000 died, including 620 in Minamisanriku. Most people submerged were among the dead. A few, however, survived, and some of them, sociologist and Sanriku native Akemi Yamauchi writes, told stories like the diver about the bleeding ocean. Finding their clothes stained crimson, they thought at first that great injury had befallen them. Later, realizing they were unharmed, they described themselves as splattered with "the ocean's blood" (umi no kaeri chi) (Akasaka et al. 2011: 116).

According to Kath Weston (2016), such instances of 'unwanted intimacy'when presumed barriers between human and non-human forces break down-increasingly characterize our historical moment. Waking us from the 'dream of modernity' and its promise to separate society from nature, each new fraught landscape, Weston argues, highlights how non-human actors permeate and shape our environments and bodies (ibid.: 5-21). Prior to the seawalls' hardening of coastal edges, Sanriku's seaboard was also characterized more by porosity than separation. People sought to protect themselves, historically, through perceiving and conceptualizing the movements of other actors-waters, animals, fish-portending coming extremes in their shared environment. By building seawalls from the 1960s onward, however, the state sought to render safety less a function of perception-which had failed people before-than of matter. For a while, this appeared to work. As a result, development rates near the coast rose (cf. Nateghi et al. 2016): believing themselves safe, residents built homes, businesses, and government facilities in places they knew had been inundated in the past. But the walls' apparent failure on 3.11 led some to question whether sea and land could be or should have been divided.

Like the woman late to flee, many believed, specifically, that their losses occurred because protective infrastructures impeded their ability to know and 
anticipate other beings and forces they depended on (including the ocean itself). In Minamisanriku, a council of residents, which had been convened to discuss the town's recovery plans, accordingly wrote that they had "seen anew the limits of disaster prevention through hard infrastructure like seawalls" (Minamisanriku-chō Shinsai Fukkō Chōmin Kaigi 2011: 9). At issue was how to "live with the ocean" (umi to tomo ni ikiru) again instead of "relying on concrete," as one member put it. "There are many things we cannot fully prevent," a community leader who lost his house summarized to me. "We can only live within the limits that nature"-including, in this case, the sea- "permits us" (shizen ga yurushite kureru hani de). But "officials" (yakunin), he continued, "haven't learned these lessons."

The engineers and the disaster scientists advising them agreed that 3.11 revealed prior seawalls' inadequacy. But they disagreed about whether the event undermined 'hard' protection more generally. To protect residents, the chairman of the national Reconstruction Design Council wrote, "we must end the history that has been repeated until now" of rebuilding seaside towns only for them to be washed away by the next disaster (Iokibe 2016: 301). To achieve this, a technical subcommittee advising the Council suggested that new, higher walls should be erected and that residents should not be permitted to rebuild along the coastline; the areas where they used to live would be turned exclusively into industrial and commercial zones (Central Disaster Management Council 2011).

Drawing on ethnographic research conducted in Minamisanriku between 2012 and 2016, I argue that the tensions between these positions and projects produced a particular kind of politics in Japan's disaster regions-what I call a politics of 'ontological dissensus'. By 'ontological', I mean related to what Philippe Descola (2014: 271-272) calls 'worlding', that is, perceiving, conceiving the nature of and relations between, and interfering with the heterogeneous forces given in our environments. As the present participle indicates, these are acts that produce the material worlds we live in and shape what-and who-we are. The term 'dissensus' I take from Jacques Rancière, redefining it as moments when people actively lodge one worlding into another while refusing the "'normal' distribution of positions" between those whose worlds count more or less (Rancière et al. 2001). I argue that conceiving resistance to seawalls in such terms not only helps us see what was at stake for residents in reconstruction; it also provides an opening to reconsider the meaning of 'politics' in 'political ontology'.

\section{Ontology and Politics}

This article dialogues with a particular understanding of 'political ontology' that has emerged within the diverse body of literature some identify as 'the ontological turn'. Two terms and their relations require parsing here: 'politics' 
and 'ontology'. Linking material-semiotic theories (Haraway 1991; Latour 1993, 2005; Law 2008; Mol 2003) and research on indigenous cosmologies (Descola 2013; Viveiros de Castro 2014), Mario Blaser (2013: 552) argues that we should understand ontologies-or 'worldings'-as products of dynamic relations within hybrid assemblages. These are separated only after the fact, if at all, into discrete objects or spheres such as 'nature', 'culture', and 'society'. Accordingly, ontological anthropology should not, he writes, characterize 'nature' as an objective foundation. Through describing other worldings, it should show how other ways of conceiving, composing, and relating human and nonhuman objects and domains are possible. Political ontology, in Blaser's sense, is thus a political project grounded in acknowledging and respecting this diversity. "Politics," Holbraad et al. (2014; original emphasis) write, becomes here "the non-skeptical elicitation of [the] manifold of potentials" that other ways of assembling reality hold "for how things could be."

However, whether these and similar conceptions of politics within the 'turn' are sufficiently 'political' has been subject to considerable recent debate (Brenner et al. 2011; Joronen and Häkli 2017; Storper and Scott 2016). There are significant differences among the views expounded by ontological theorists and ethnographers. What their critics have in common, however, is skepticism regarding how and if ontological insights can inform political analysis concerned with power's consolidation and effects: what political scientist Harold Lasswell (1950) called 'who gets what, when, how'. Bessire and Bond (2014), for example, argue polemically that ontologically minded anthropologists, including Blaser, Viveiros de Castro, and Descola, neglect the workings of domination and inequality that are central to politics. Political theorist William Connolly (2017: 96), in a more appreciative engagement with the same scholars, advocates that ontological writing more explicitly "connect the theme to specific engagements with, say, freedom, ... the role of neoliberal capitalism, ... and interim struggles of political action," to name but a few issues.

In response, this article examines the seawall controversy to show how, and when, ontological diversity became politicized in Northeast Japan and what this implies for political ontology. I explain this through reference to what, drawing on Rancière, I call 'ontological dissensus'. Ontological theorists have approached Rancière's work somewhat ambivalently. Some draw inspiration from it (Blaser 2013; Booth and Williams 2014; Cadena 2015). Others, like Jane Bennett (2010) and Graham Harman (2011), argue that Rancière epitomizes humanist theory's exclusion of non-human agency, exhibiting concern only for "the unequal treatment of beings who are equally endowed with the capacity for human speech" (Bennett 2010: 106; original emphasis). Bennett, however, also recognizes that Rancière's work holds potential for ontological theory. This potential, I argue, lies in his conception of politics as dissensus: the lodging of subordinated ways of partitioning the sensible world 
into dominant ones (Rancière et al. 2001). In the remainder of this article, I elaborate this thesis through an analysis of the seawall controversy and the dissensus it precipitated.

At the heart of my argument is the ocean that seawalls sought to exclude and that residents claimed bled during the tsunami. One could probably explain the latter phenomenon scientifically, Yamauchi writes, but to do so would remove something crucial: "If we reduced those stories to science in telling them, they would inevitably lose 'pain'. And a story emptied of pain"-both human and that of the ocean itself-cannot participate in recovery (Akasaka et al. 2011: 116). In other words, we should not try to explain away attribution of hurt to the sea. Nor should we assume, per Blaser, that human and non-human forces require different kinds of stories. In the histories of what Yamauchi (2016) has elsewhere called 'the Sanriku world', bones of beached animals could become manifestations of deities, and fishermen drowned at sea, in turn, could become like fish (Kawashima 2017: 128). Instead, we should ask what different practices of detecting, framing, and relating these forces might reveal about reconstruction and, crucially, its politics.

In attempting to do so, I draw on fieldwork carried out among tsunami survivors for a wider project on how they conceived, experienced, and practiced reconstruction. As much research to date attests, reconstruction was largely a top-down process that neglected, or at best struggled to incorporate, survivors' needs and views (Aldrich 2019), and my project, accordingly, focused on making this visible. This article, similarly, is a form of "writer-activism" (Nixon 2011: 14) concerned with showing why residents resisted something that many officials insisted would make them safer. This does not mean that the former were united, or that the latter's voices and actions were univocal or uniform. Different levels and bodies had conflicting interests, assumptions, and practices. Some local officials (who, after all, lived in the places being reconstructed) refused seawalls, while others-anxious about their ability to access wider recovery funding-followed prefectural and central government guidelines with considerable unease.

What linked state organs and actors, however, was a particular understanding of tsunamis channeled through policy documents emanating from the Cabinet Office downward. We will first turn to how this theory's crafting by tsunami scientists and engineers and its promotion by key officials within governance hierarchies set in motion the Northeast coast's restructuring. I then describe other ways of assembling coastal worlds that were threatened before showing how, in the following section, survivors dissented by lodging alterations into seawall projects. Building on Rancière, I conclude that a theory of ontological dissensus explains better than appeals to difference per se how "ontological realities become eventfully politicized" (Joronen and Häkli 2017: 568), affecting who gets what, when, and how. 


\section{Enclosing Society}

The government began building walls in Northeast Japan following the 1933 Shōwa Sanriku tsunami. Initially, they were made mostly of compacted soil. The 1959 Ise Bay typhoon, however, washed these away, and it was subsequently decided that future structures must be "armored by concrete" on all sides (Shuto and Fujima 2009: 269). After the 1960 Chile earthquake and tsunami, the number of walls increased significantly (Ando et al. 2000), marking a paradigm shift in disaster mitigation methods. Previously, affected locales would erect stone monuments (kinenhi) after tsunamis, marking the inundation zone, describing the casualties, or warning people to stay vigilant. These, Shuhei Kimura (2016: 32) argues, "added to the everyday landscape of communities," whereas the new walls, by contrast, sought to "enclose" them by separating them from the sea. When the 1968 Tokachi-Oki tsunami struck the deep north, they prevented inundation, leading many people to conclude that "there would be no threat of tsunami in the future" (Shuto and Fujima 2009: 270). Much of the Northeast coast's development dates from this period. In Minamisanriku and neighboring towns, government offices, hospitals, and high schools were erected in areas known to have been flooded previously. So long as the walls held, both the assumptions they concretized and the development they stimulated went unquestioned. When they fell apart on 3.11, however, both became visible again and open to contestation (Star and Ruhleder 1996).

In September 2011, a scientific subcommittee comprising civil engineers, tsunami modelers, and other disaster scientists advising the Reconstruction Design Council released a report acknowledging that the tsunami "exposed the limitations of disaster management measures that rely on coastal protection facilities to an excessive degree." However, they argued that these facilities remain "the basic and vital measures in the promotion of comprehensive tsunami countermeasures" (Central Disaster Management Council 2011: 6-16). "With the 'soft side' [sofuto men], you only have evacuation," an involved hydraulic engineer put it (Kensetsu Tsūshin Shimbun 2016). "Tsunamis," a modeler advising the government further explained, are basically just "external pressure [gairyoku]"; against this, "walls [kabe] like seawalls and river embankments are crucial” (Bōchōtei wo Benkyō-Suru Kai 2012: 5-8). The problem, the Council's scientific subcommittee summarized, was less engineering overreach than engineers not properly understanding and classifying events, leading to insufficient protective systems.

Before 3.11, for example, tsunami modelers based their assumptions about possible Japan Trench tsunamis on information only from the smaller disasters characterizing the past few hundred years due to incomplete historical data. The result was an event, in their words, "beyond expectation" (sōteigai) on 3.11. In the months following, researchers sought to right the balance by 
incorporating data on it and other historical tsunamis into their models. This entailed combing the rubble for its signs: from stopped clocks, they estimated time of arrival; data from GPS buoys suggested its waveforms; finally, damage to the built and natural environment testified how far it had reached inland (Muhari et al. 2012). By amalgamating these heterogeneous traces with archaeological ones, they crafted two new categories of object requiring not only new seawalls, but an expanded system of coastal protection more broadly.

"Developing future tsunami countermeasures," the subcommittee wrote, "will basically require the assumption of two levels of tsunamis" (Central Disaster Management Council 2011: 10). The first are smaller and more frequent events like those that previous walls were designed to stop. They called these Level 1, or L1, tsunamis, arguing they should be prevented from penetrating inland by building higher seawalls. The second, which they called Level 2, or L2, are extremely large and rare events like that which occurred on 3.11. Seawalls cannot prevent them. Accordingly, they recommended mitigating their effects through 'disaster reduction' (gensai) measures-most notably, preventing rebuilding in 'disaster danger zones', which would be determined partially by the height of the new seawalls. Residents whose homes fell inside them would need to be relocated, they proposed. These zones would then be subdivided into exclusively industrial or commercial areas. To consolidate them, municipalities would have to reorganize and rationalize land use while increasing municipal and prefectural ownership of shorelines.

The committee advocated, in short, what historians of tsunami countermeasures have called a 'total system' of protection (Shuto and Fujima 2009). Its totality derives from both re-armoring coastal towns and, unlike prior efforts, also reorganizing and policing their internal boundaries to mitigate L2 tsunami damage. Infrastructures, including seawalls, would contribute by delineating and structuring new relations between spaces and elements (Jensen and Morita 2017: 617). By combining these 'hard' changes with 'soft' social measures, like improved evacuation procedures, the system's architects sought, I suggest, to better 'saturate' coastal space. Saturation refers, in Rancière's work, to a situation when all parts and parties are accounted for and assigned proper places, leaving no excess or surplus (which he calls the 'unaccounted for') (see Dikeç 2005: 175). Through accounting for parts, allocating parties 'safe' locations, and incarcerating the sea beyond society's edge, the committee contended that the new system would put fewer lives at risk, should an L2 tsunami penetrate in future.

In summary, to better saturate coastal space, central government officials proposed deepening control of it through new infrastructural development, land-use restrictions, and land transfers. However, the plans were not uniformly appreciated or enacted by prefectures and municipalities, refracted as they were through local governments' own concerns. Some towns chose not to 
build seawalls, or to creatively combine raised embankments with other infrastructures like roads (Onoda et al. 2018). In Minamisanriku's Miyagi Prefecture, however, Governor Murai pushed for the system's full adoption. Planners divided their stretch of coastline into 22 topographical units. Based on simulations by tsunami modelers, they established seawall heights for each unit, which they then pressed municipalities to accept. As Onoda et al. point out, the simulations did not account for particular hamlets' populations, building densities, or topographies (ibid.: 5). This led, in some cases, to walls being planned for entirely unpopulated areas (NHK 2015). However, as residents would show, hamlets' degree of habitation was, in fact, far from the only thing unaccounted for within the total system's conception and enactment.

\section{Dividing Other Worlds}

In late 2015, I visited a seawall site north of Minamisanriku with Satō, a local activist, and his son. ${ }^{2}$ Forty-three of the area's approximately 1,800 residents had died during the tsunami, and close to 70 percent of homes were mostly or partially destroyed. In the aftermath, Miyagi Prefecture announced plans to erect a seawall 14.7 meters high and 90 meters wide-the largest in the area. Satō took me to a viewing platform where we could overlook the site. With displaced residents relocated, it was not clear what the wall was for. Satō told me: "They say they are building it to protect property," like nearby aquaculture facilities. On the platform were maps depicting what the waterfront was intended to look like when the work was finished. "All the images are from above," Satō's son commented. "Yes," Satō replied, "they never look at things from people's point of view."

Miyagi Prefecture promulgated its objectives to residents, including Satō, a year or so after the disaster in small, sometimes fractious meetings along the coastline. Residents would question both the proposed heights, which ranged from 5 to 14.7 meters, and the simulations behind them; many asked for the former to be lowered. This, officials invariably replied, was not possible (although I did not personally attend early meetings, I witnessed this reported intractability frequently in later ones). ${ }^{3}$ One reason given post factum for their reluctance was the total system's interconnections: changing heights would mean altering the zoning dependent on them, requiring new rounds of simulation and planning that few officials, worried about the limited time available for accessing recovery funding, wanted to consider (Onoda et al. 2018). Another, less generous reading is Kimura's (2016: 37), who claims that officials' "compartmentalized and rigid ... administrative structure [in which] each level internalizes the authority of those above" explained their unwillingness to change plans. After all, those presenting were not, in most cases, 
decision makers. They argued, in any case, that walls were necessary for future safety. If they "explained this carefully" (teinei ni setsumei suru) enough, several told me, residents would surely understand. But increased understanding of how the walls would divide them from the sea often prompted more, not less, resistance from survivors (ibid.).

Tsunamis may be 'external pressures' (gairyoku), but residents like Satō told me how their lives and identities are intertwined with the sea: historically, oceanic forces have penetrated and structured Sanriku worlds and vice versa. One finds traces of these entanglements in the worship of objects washed ashore, from rocks to bones, as manifestations of deities like Ryūjin or Ebisu, whose humors both protect and imperil fishermen. Many religious activities also take place on or in the water. These vary from district to district, even within towns, according to which spirits are immanent in nearby land and seascapes and local histories about relating to them. ${ }^{4}$ When launching a new boat, for example, fishermen in Shizugawa parade it around and make offerings to Areshima, a sacred island near the waterfront whose deities, including Ryüjin, watch over the waters. At the end of the Obon festival, when departed ancestors briefly return to visit their family homes, residents of the same district gather near river mouths and light their way back to the other world by floating lanterns out to sea.

Satō and many others also told me how, in daily life, people depend on and nurture more profane exchanges and presences, both across the landwater boundary and within the bays. Minamisanriku is famous for aquaculture: its coastal inlets contain not only deities and departed spirits, but also intricate networks of undersea pastures, where fishermen cultivate scallops, oysters, seaweed, and hoya (sea pineapples). The vitality of these dominions depends, he said, on the flow of rainwater from the mountainous interior, which brings terrestrial minerals that fertilize the water. Seawalls divide land and sea, impeding the final steps in this sequence: the larger the wall, the less fertile the rainwater. Another, related effect is altered flows within the shallows themselves. A community organizer from northern Minamisanriku, who also lived and worked near the waterfront, explained to me: "The ocean currents change. The flow of the ocean, you know. When that happens, there are lots of marine plants and suchlike that attach to the rocks, and they detach. Places where urchins and abalone would anchor, you can't find them anymore ... places that were good for fishing until now, they become totally useless."

I heard many similar concerns about seawalls altering the assemblages of aquatic life that people farm beyond the town's hardening edge. ${ }^{5}$ More of the people I spoke to, however, worried about how new infrastructures would impede their ability to perceive these assemblages. Worldings assemble ecologies of practices, only some of which are our own, that we inhabit and 
attune to. This attunement-an ongoing process of detecting, categorizing, and attending to things moving around us-is, in turn, part of world-making's cycle (Stewart 2011). Time and again, people told me that they opposed walls because they would block views of the sea and thus impede attunement with oceanic forces. For example, fishermen and aquaculturalists, most of whom live and work by the waterfront, must monitor the ocean's daily moods and tempers-its unadara or 'expressions'. By reading the face of the water, the quality of the clouds, and the strength and direction of the wind, they decide their fishing strategies, including whether to fish at all (Kimura 2016: 28). This attuning cultivates what Jonathan Kramnick (2015) calls an 'aesthetics of presence'. Grounded in continual perceptual engagement, it constructs the ocean not only as an object of knowledge but also as an active subject within coastal society. The sea becomes, in the words of Sanriku folklorist Kawashima (2017: 282), "one enormous living being" that people work with, by, and through.

Many survivors, as I have already alluded to, believed that not seeing this 'being' had made them less safe during 3.11. Prior to the erection of the first seawalls, residents sought to protect themselves by propitiating the spirits inhabiting the sea. They also tried to anticipate tsunamis and gauge their severity by attuning to other things whose movements portended them. For example, ten days before an event, as Minamisanriku's official history recalls, well water would become like oil. Strange ghost lights would appear at sea, and tides would reach higher than usual. Eels, sardines, and squids would gather in great numbers in deeper water; mice, meanwhile, would evacuate the coast (Shizugawa-chō shi henshū-san shitsu 1989: 346-347). Successful prediction required enough familiarity to read these signs. Few, if any, residents use wells today or are as familiar with the comings and goings of mice. But many still watch after earthquakes for another movement: the tide leaving unexpectedly. During 3.11, some workers in harbors or at sea managed to save their boats by following the withdrawing water into the bay-the safest place during a tsunami. Like the diver confronting the bleeding ocean, their attunement saved them and their boats. The previous walls had already affected this ability to anticipate tsunamis. The new ones, they believed, would degrade it further by hiding the ocean everywhere except the immediate waterfront or faraway highlands.

People feared, in summary, that walls would leave them oblivious when the next tsunami came by dividing them from a non-human being around which their worlds revolved: the sea. But walls do not only divide. They also erase. I learned this from Tomoyuki Miura, a well-known anti-seawall activist whom I first interviewed in a trailer overlooking a small port in northern Minamisanriku. That morning, both harbor and water were empty. The waves were high and strong, smashing the breakwater again and again in explosions of spray. Miura pointed to the sea, his finger tracing an invisible line where the new 
seawall would reach. At 8.7 meters high, nearly three stories, it would double the height of the existing breakwater. Most of the harbor and the whole road behind it, he told me, would disappear under its wide base.

Miura is from Ōya, a coastal subdivision of Kesennuma, a city some 27 kilometers north of Minamisanriku. In an essay titled "In the Midst of a Changing Landscape," Miura (2015: 91-92) describes a meeting between officials and residents in June 2012, supposedly called to explain Ōya's new disaster danger zone, where rebuilding would be prohibited: "Some 300 people were sitting on the floor listening ... Suddenly, they began to explain about the wall. A shocking plan to fill in the whole beach by constructing a concrete seawall $9.8 \mathrm{~m}$ high, with a width of $40 \mathrm{~m}$, that pushes out into the ocean." One effect of this would be the loss of Ōya's entire beach, which served as both a tourist attraction and site where residents held festivals, learned to swim, and became generally intimate with the ocean and its life. Miura showed me a letter, delivered in August 2015 to Kesennuma's mayor by the head of Ōya's main resident association, explaining what losing this beach, "Ōya's symbol," would do to them. To concrete it over would take away "their pride and joy" and impede their ability to revive "a way of living that keeps the ocean and the coast alive." It would also mean losing their "identity as a place" (chiikisei)-their "Ōya-ness" (Ōya-rashisa). Alongside threatening the exchanges and presences they depended on, the walls threatened, in Ōya and elsewhere, the identities built on or around them. Little wonder, then, that such plans provoked dissensus.

\section{Ontological Dissensus}

At Minamisanriku's northernmost edge you will find a small hamlet called Kitahama. The tsunami, channeled by its long, narrow valley, took all the houses there. However, most people escaped unharmed by following informal paths up the steep sides to safety. In 2012, I met Kitahama's leader, Kudō, along with several architects and planners visiting from the United States. Kudō told us about the plans to protect the valleys with an 8.7-meter seawall. He knew this would eliminate most of the existing harbor and block all views of the sea. However, he said that officials' insistence on using bird's-eye-view zoning and planning maps in meetings made it difficult for other residents to grasp this. When I asked a local government worker why this was so, he told me it was because they must legally give only precise, accurate information. While zoning and planning maps were undeniably accurate, they were also hard to read. Kudō asked, accordingly, if we could help by preparing other visualizations of what the seawalls would look like and surveying opinions on them. 
To mirror literal worldviews, we decided to take eye-level photographs from the main roads entering the harbor, superimpose seawalls of various heights, and attach these images to a survey distributed by Kudō. A few days later, I sat in a meeting room with residents while a colleague projected the results on a sheet pegged to the far wall. Thirty-six of the 45 displaced households had responded: a super-majority (67 percent) had rejected the planned seawall height, although none had chosen no wall at all. Most desired a wall that was 4 meters or lower; the most popular option was 2 meters (the same as before the disaster) with 42 percent support. While we explained these results, the room was quiet, but when we projected the 8.7-meter image, it came angrily to life. One fisherman, pointing at it, shouted he would rather leave the town for good than permit such a wall. When I next returned to Kitahama two years later, I visited Kudō to ask what had happened since that meeting. He told me that he immediately took our report to a meeting with local government officials and "hurled it at them." Then he began organizing residents.

Previously, I discussed how seawall projects are helping saturate coastal space, delineating and distributing its elements without accounting for residents' ways of conceiving them and their relations. Here, I examine how such unaccounted-for ideas and practices became politicized in places like Kitahama through what, building on Rancière (1999, 2010), I call 'ontological dissensus'. Rancière situates his work in opposition to what he considers the hegemonic understanding of politics. Political analysis, he argues, typically focuses on how power flows within stable 'partitions of the sensible', determining who gets what, when, and how. By 'partition of the sensible', he means the dividing of the world into "groups dedicated to specific modes of action ... places where these occupations are exercised [and] modes of being corresponding to these occupations and these places" (Rancière et al. 2001). He argues that a drive to saturate, to ensure that all groups, places, and modes are properly distributed and controlled, underpins dominant modes of partitioning-and for this reason, he calls them 'the police'.

Politics, Rancière continues, emerges when people challenge these ways of delineating and relating groups, places, and modes of being. It is not enough, he says, that people believe in or voice different ones; ideational diversity is not political in and of itself. Rather, "words must be borne by bodies" (Rancière 2016: 152) in acts lodging subordinated partitions of the sensible into more powerful ones. Such acts stage an excess within the latter: the presence of things invisible, unaccounted for, or given no part. And they mobilize that excess to reconfigure realities in ways accommodating it. This is why politics, he writes, "is first and foremost an intervention upon the visible ... [it] makes visible that which had no reason to be seen, it lodges one world into another" (Rancière et al. 2001). And it does so in the name of equality between those whose worlds count more or less. As critics like Bennett (2010: 106) point out, 
Rancière's idea of 'world' contains only human subjects and their relations. But his theory, if expanded to include non-human actors and modes of being related to them, helps us to understand how ontological multiplicity became politicized in places like Minamisanriku.

In the town and its environs, dissenting residents spoke of worlds in which the ocean was a 'living being' that required continual access and monitoring. They also sought to lodge these worlds into the total system's restructuring of coastal space. Sometimes they used existing channels between residents and various levels of the state. In Kitahama, Kudō could 'hurl' our data at officials because he was the head of a self-governing association (gyōseiku): the lowest rung within Japan's nested hierarchy of government. Many dissenters also created new organizations. Groups opposing seawalls sprang up across Miyagi. Some tactically articulated with existing collectives, as in Ōya, where Miura persuaded a network of community organizations to adopt his new pressure group agitating against the district's seawall plans. Through these strategies and others, people tried to force their visions onto the agenda of those tasked with planning and carrying out reconstruction projects.

First, of course, this entailed refusing existing plans for their areas. Residents owned much of the coastal land needed for walls, requiring state organs to purchase it (Kahoku Shimpō 2015). If the landowners refused, projects could not go ahead. It is hard to gauge how many seawalls were held up by such refusals. In Kesennuma alone, however, two years after the city first circulated its plans, 18 percent of the 87 scheduled areas were still holding out (Sangyō-bu Suisan Kiban Seibi-ka 2014), despite reported threats to not rehouse people absent agreement. In some areas, including the town of Onagawa, people decided to reject seawalls entirely. Communities in Kesennuma's Hashikami and parts of Watari city, among others, pushed to replace walls with protective forests (Rots 2019), or began creating their own safety infrastructures drawing on and attuned to local worlds, such as escape routes following animal trails (kemonomichi) into the hills.

Most of those who still resisted, however, wanted some degree of structural protection. In my research areas, the majority wanted lower heights, allowing them to maintain ocular interconnections and reduce spatial erasure (with nearly half of Kitahama's evacuees, as noted, desiring a 2-meter wall). But such requests prompted strong pushback from the prefecture, as changing heights would have a cascade effect on zoning plans writ large, delaying recovery. Seeing this, some activists shifted from outright resistance to lodging alterations into seawall plans that would enable them to retain their relationship with the sea. In Shizugawa, the head of one pressure group told me: "We started talking about things other than height, like the shape or the inclination or things like that; the location of stairs, the width ... if you didn't make requests about those kinds of things you'd just lose time on height. So we shifted to not talking 
about [that] and making detailed requests about the structures. Then, even though I hate the height, we could ask for things bringing [the wall] as close as possible to our ideals." As I described earlier, for example, in Minamisanriku people direct spirits back to the other world by floating lanterns out to sea. Raising and concreting riverbanks close to harbor mouths prevented this, so the group lobbied for staircases on Shizugawa's river walls, which would allow residents easier ritual access to the water. They asked for small alterations that would lodge some of their worlding practices into projects that would otherwise mitigate them.

Another tactic they pursued was moving seawalls farther inland or out into the bay, preserving most existing connections across the land-water interface. In a hamlet that Kimura (2016) calls Maehama, for instance, residents pursued this tactic to preserve not only views of the sea but also an important shrine that the wall's base would obliterate. Those building the walls sometimes acceded, if pressured, when changes would not threaten their wider reworking of coastal space. After 'hurling' their objections at officials, for example, Kitahama's community held a series of meetings between themselves and officials, finally persuading the latter to move the seawall 100 meters farther inland, retaining the entire harbor. Due to the valley shape, this would also reduce the wall's length to less than a third of what was originally planned. In Ōya, Miura's group also focused on moving their wall. In 2015, however, he wrote of his surprise when, on delivering a petition signed by more than a third of Kesennuma's residents, the mayor told him they were already planning to set the wall back and combine it with a new highway, preserving the existing waterfront.

"Suddenly," Miura (2015: 95) wrote, "common ground had been carved out between residents, and between residents and the administration: a moment when we had partially reached consensus." In places like Ōya and Kitahama, such consensus resulted, beyond the walls, in spaces where sea and society could continue constituting each other despite the total system. This did not mean that a 'common world' (Latour 2004) had emerged: the coast was still host to multiple, incommensurable ones. But boundaries had been redrawn enabling some worlds to co-exist without interrupting or impeding each other. Of course, disagreements between residents like Miura and the city administration over who got what, when, and how continued. However, these disagreements no longer revolved, or revolved less, around conflicting ways of conceiving and relating the world's parts and contours. One can imagine a history of the political tracking the back and forth between ontological and regular politics, although such a history is beyond the scope of this article. Within regular politics, ontological politics remains a latent possibility due to ontological multiplicity: the excess, or "otherwise" (Holbraad et al. 2014), waiting, through the interruptive act of dissensus, to become visible and 'political'. 


\section{Conclusion}

Within the growing body of literature often grouped as 'the ontological turn', some have argued that the existence of multiple ontologies is, itself, political. "To differ," Holbraad et al. (2014) write, is "a political act." Blaser (2016: 550), similarly, partially defines politics as "differences that are potentially the ground for disagreement." By challenging our ontological assumptions, they argue, these differences can show that other ways of perceiving, conceiving, and relating human and non-human beings and domains are possible. However, critics have questioned the degree to which such arguments, and the research they motivate, contribute toward our understanding of politics conceived in other terms (Joronen and Häkli 2017: 568), such as struggles over who gets what, when, and how. In this article, I have suggested that seawall plans and the ontological dissensus they precipitated provide an opening through which to further these debates by reconsidering the 'politics' in political ontology.

Drawing on Rancière's political theory, I have argued that ontological multiplicity becomes politicized when not only asserting but also enacting difference becomes the means of struggle against domination. Here, resolving who gets what, when, and how hinges for a time on struggles over who is who, what is what, and how they should be related and distributed. There are innumerable actual and possible differences that can be activated, not all of which are related to visible things, and they can become politicized, of course, due to events other than disasters. Northeast Japan certainly hosted many ways of partitioning the sensible world, both pre- and post-tsunami. This includes ones where the coast was not a line but an assemblage, in which fishermen, spirits, deities, waters, oysters, scallops, and other beings were entangled with and constituted each other. After the disaster, these entanglements became politicized due to reconstruction's most contentious issue-the decision to ensure future safety by building seawalls.

Struggles by people like Kudō and Miura to insert unaccounted-for practices into seawall projects did lead to significant changes, although not as significant as they had hoped. As of January 2016, plans had been altered in nearly a third of all sites: 27 in Iwate, 154 in Miyagi, and 1 in Fukushima (Kahoku Shimpō 2016). However, few people resisted completely. In most places, including Kitahama, walls still went up. I last visited Kudō in the summer of 2016. When I asked how seawall construction had progressed, he offered to show me. We drove around several neighboring construction sites, arriving, lastly, at one concreting over a beloved beach. Despite its comparatively gentle gradient, standing at the bottom of the wall I was struck by its height. All that was left of the former coast were shattered black stones filling the gap between the slope and tetrapods lining the shallows. Kudō squatted on the wall, smoking and 
watching the sea. Having lost so much, he was not immune to desire for protection. But he sought, instead, something else-to reassemble a world where the ocean, the source of both bounty and fear, was always within his sight.

\section{Acknowledgments}

I owe thanks to many people, not least the people of Minamisanriku. Theodore C. Bestor, Ajantha Subramanian, Andrew Gordon, Nicolas SternsdorffCisterna, Elsa Charlety, Annemarie Samuels, and many others helped me to find the argument's direction; the anonymous reviewers and Martin Holbraad pushed me to improve it further. The research on which this article is based was funded by grants from the Japan Foundation and the Reischauer Institute of Japanese Studies.

Andrew Littlejohn is an Assistant Professor at Leiden University's Institute of Cultural Anthropology and Development Sociology. Prior to joining Leiden, he held a Postdoctoral Fellowship in the Weatherhead Center for International Affairs' Program on U.S.-Japan Relations at Harvard University, where he also received his $\mathrm{PhD}$ in Social Anthropology with a secondary field in Critical Media Practice. The core question motivating his current research is how to live sustainably in a world damaged by both intensifying hazards and the technologies developed to mitigate them. E-mail: a.1.littlejohn@fsw.leidenuniv.nl

\section{Notes}

1. Unless otherwise indicated, all translations are my own.

2. With the exception of municipalities, regions, and published authors, all names of people and places are pseudonyms.

3. While heights could not be tweaked, it was, in fact, possible to refuse the new walls and simply restore pre-disaster ones, although this option was often not made clear to residents, who tended to believe that they had no choice (Kimura 2016).

4. In Shinto, spirits or kami reside within, rather than outside, the world.

5. Biologists have made similar claims (see Nature Conservancy of Japan 2013). 


\section{References}

Akasaka, Norio, Eiji Ōguma, and Akemi Yamauchi. 2011. Tōhoku saisei [Reviving the Northeast]. Tokyo: East Press.

Aldrich, Daniel P. 2019. Black Wave: How Networks and Governance Shaped Japan's 3/11 Disasters. Chicago: University of Chicago Press.

Ando, Akira, Yoshihiro Sasaki, Ryūichi Akatani, and Tsuyoshi Miura. 2000.

"Iwate-ken enganiki no tsunami bōsai ni kansuru shiteki kenkyū" [A historical study on tsunami disaster prevention of the coastal area in Iwate]. Doboku Gakkai Ronbunshu 639: 1-11.

Bennett, Jane. 2010. Vibrant Matter: A Political Ecology of Things. Durham, NC: Duke University Press.

Bessire, Lucas, and David Bond. 2014. "Ontological Anthropology and the Deferral of Critique.” American Ethnologist 41 (3): 440-456.

Blaser, Mario. 2013. "Ontological Conflicts and the Stories of Peoples in Spite of Europe: Toward a Conversation on Political Ontology." Current Anthropology 54 (5): 547-568.

Blaser, Mario. 2016. “Is Another Cosmopolitics Possible?” Cultural Anthropology 31 (4): 545-570.

Bōchōtei wo Benkyō-Suru Kai. 2012. Dai-11 'bōchōtei wo benkyō-suru kai' gijiroku [Minutes of the 11th Seawall Study Group]. https://seawall.info/pdf/11120927-giji.pdf.

Booth, Kate, and Stewart Williams. 2014. "A More-Than-Human Political Moment (and Other Natural Catastrophes)." Space and Polity 18 (2): 182-195.

Brenner, Neil, David J. Madden, and David Wachsmuth. 2011. "Assemblage Urbanism and the Challenges of Critical Urban Theory." City 15 (2): 225-240.

Cadena, Marisol de la. 2015. Earth Beings: Ecologies of Practice across Andean Worlds. Durham, NC: Duke University Press.

Central Disaster Management Council. 2011. Report of the Committee for Technical Investigation on Countermeasures for Earthquakes and Tsunamis Based on the Lessons Learned from the "2011 off the Pacific Coast of Tohoku Earthquake." Report to the Cabinet Office, Government of Japan. http://www.bousai.go.jp/ kaigirep/chousakai/tohokukyokun/pdf/Report.pdf.

Connolly, William E. 2017. Facing the Planetary: Entangled Humanism and the Politics of Swarming. Durham, NC: Duke University Press.

Descola, Philippe. 2013. Beyond Nature and Culture. Trans. Janet Lloyd. Chicago: University of Chicago Press.

Descola, Philippe. 2014. "Modes of Being and Forms of Predication.” HAU: Journal of Ethnographic Theory 4 (1): 271-280.

Dikeç, Mustafa. 2005. "Space, Politics, and the Political.” Environment and Planning D: Society and Space 23 (2): 171-188.

Haraway, Donna J. 1991. Simians, Cyborgs, and Women: The Reinvention of Nature. New York: Routledge.

Harman, Graham. 2011. “Autonomous Objects.” New Formations 71: 125-130. 
Holbraad, Martin, Morten Axel Pedersen, and Eduardo Viveiros de Castro. 2014. "The Politics of Ontology: Anthropological Positions." Theorizing the Contemporary, Fieldsights, 13 January. https://culanth.org/fieldsights/462-the -politics-of-ontology-anthropological-positions.

Iokibe, Makoto. 2016. Daisaigai no jidai [The era of great disasters]. Tokyo: Mainichi Shimbun Shuppan.

Jensen, Casper Bruun, and Atsuro Morita. 2017. "Introduction: Infrastructures as Ontological Experiments.” Ethnos 82 (4): 615-626.

Joronen, Mikko, and Jouni Häkli. 2017. "Politicizing Ontology.” Progress in Human Geography 41 (5): 561-579.

Kahoku Shimpō. 2015. "Bōchōtei: Gōi wa doko made? Ken 'chikensha de jūbun.” [Seawalls: How much consensus is necessary? Prefecture says "Landowners only"]. 24 February (accessed 5 October 2016).

Kahoku Shimpō. 2016. "Bōchōtei: Kensetsu 3 ken de sa: Teinei na setsumei fukaketsu.” [Seawalls: Gap between 3 prefectures: Careful explanation necessary]. 3 January (accessed 6 November 2016).

Kawashima, Shūichi. 2017. Umi to ikiru sahō: Ryōshi kara manabu saigaikan [How to live with the sea: Learning from fishermen's views on disaster]. Tokyo: Fuzanbō International.

Kensetsu Tsūshin Shimbun. 2016. “Tsunami higai: Biggudēta kaiseki de 'bōchōtei/ rin wa akueikyō nashi'. Tohokudai no Burikā Jeremī jun kyōju ni kiku” [Tsunami damage: Big data analysis says "Sea breakwaters and forests have no adverse effects.” Interview with Associate Professor Bricker Jeremy of Tohoku University]. 28 August. http://kensetsunewspickup.blogspot.com/2016/08/ blog-post_67.html.

Kimura, Shuhei. 2016. "When a Seawall Is Visible: Infrastructure and Obstruction in Post-tsunami Reconstruction in Japan.” Science as Culture 25 (1): 23-43.

Kramnick, Jonathan. 2015. “An Aesthetics and Ecology of Presence.” European Romantic Review 26 (3): 315-327.

Lasswell, Harold D. 1950. Politics: Who Gets What, When, How. New York: Peter Smith.

Latour, Bruno. 1993. We Have Never Been Modern. Trans. Catherine Porter. Cambridge, MA: Harvard University Press.

Latour, Bruno. 2004. "Whose Cosmos, Which Cosmopolitics? Comments on the Peace Terms of Ulrich Beck.” Common Knowledge 10 (3): 450-462.

Latour, Bruno. 2005. Reassembling the Social: An Introduction to Actor-Network Theory. Oxford: Oxford University Press.

Law, John. 2008. "Actor Network Theory and Material Semiotics.” In The New Blackwell Companion to Social Theory, ed. Bryan S. Turner, 141-158. Oxford: Blackwell.

McCormack, Gavan. 1995. “Growth, Construction, and the Environment: Japan’s Construction State.” Japanese Studies 15 (1): 26-35.

Minamisanriku-chō Shinsai Fukkō Chōmin Kaigi. 2011. Fukkō e watashi-tachi no omoi [Our thoughts on reconstruction]. Report to Minamisanriku Town Council. 
https://www.town.minamisanriku.miyagi.jp/index.cfm/6,309,c,html/309 /2192.pdf.

Miura, Tomoyuki. 2015. "Kawariyuku keshiki no naka de” [In the midst of a changing landscape]. In Gōsuto taun kara shisha wa denai [Nobody dies in a ghost town], ed. Eiji Ōguma and Norio Akasaka, 83-100. Kyoto: Jinbunshoin.

Mol, Annemarie. 2003. The Body Multiple: Ontology in Medical Practice. Durham, NC: Duke University Press.

Muhari, Abdul, Fumihiko Imamura, Anawat Suppasri, and Erick Mas. 2012. "Tsunami Arrival Time Characteristics of the 2011 East Japan Tsunami Obtained from Eyewitness Accounts, Evidence and Numerical Simulation.” Journal of Natural Disaster Science 34 (1): 91-104.

Nateghi, Roshanak, Jeremy D. Bricker, Seth D. Guikema, and Akane Bessho. 2016. "Statistical Analysis of the Effectiveness of Seawalls and Coastal Forests in Mitigating Tsunami Impacts in Iwate and Miyagi Prefectures.” PLOS ONE 11 (8): e0158375. https://doi.org/10.1371/journal.pone.0158375.

Nature Conservancy of Japan. 2013. "Kono mama de ii no ka? Bōchōtei keikaku” [Is this OK? The seawall plans]. Shizen Hogo, July. https://www.nacsj.or.jp/ archive/2013/07/1221/.

NHK. 2015. Shinsai hisaichi: Bōchōtei ni arata na kadai [The disaster regions: New questions over seawalls]. http://www.nhk.or.jp/ohayou/marugoto/2015/09/ 0925.html.

Nixon, Rob. 2011. Slow Violence and the Environmentalism of the Poor. Cambridge, MA: Harvard University Press.

Onoda, Yasuaki, Haruka Tsukuda, and Sachi Suzuki. 2018. "Complexities and Difficulties Behind the Implementation of Reconstruction Plans after the Great East Japan Earthquake and Tsunami of March 2011.” In The 2011 Japan Earthquake and Tsunami: Reconstruction and Restoration, ed. Vicente SantiagoFandiño, Shinji Sato, Norio Maki, and Kanako Iuchi, 3-20. Cham: Springer.

Rancière, Jacques. 1999. Disagreement: Politics and Philosophy. Trans. Julie Rose. Minneapolis: University of Minnesota Press.

Rancière, Jacques. 2010. Dissensus: On Politics and Aesthetics. Ed. and trans. Steve Corcoran. London: Continuum.

Rancière, Jacques. 2016. Film Fables. Trans. Emiliano Battista. London: Bloomsbury Academic.

Rancière, Jacques, Davide Panagia, and Rachel Bowlby. 2001. "Ten Theses on Politics.” Theory \& Event 5 (3). doi:10.1353/tae.2001.0028.

Rots, Aike P. 2019. “Trees of Tension: Re-Making Nature in Post-Disaster Tohoku.” Japan Forum, 28 June. https://doi.org/10.1080/09555803.2019.1628087.

Sangyō-bu Suisan Kiban Seibi-ka. 2014. Bōchōtei no seibi keikaku ni tsuite [Regarding seawall repair plans]. Higashi Nihon Daishinsai Tokubetsu Iinkai shiryō. https://www.kesennuma.miyagi.jp/sec/s019/010/010/020/026/261111/ 3100261111iinkai_08.pdf.

Shizugawa-chō shi henshū-san shitsu, ed. 1989. Shizugawa-chō shi II [A history of Shizugawa Town II]. Shizugawa: Shizugawa-chō. 
Shuto, Nobuo, and Koji Fujima. 2009. "A Short History of Tsunami Research and Countermeasures in Japan." Proceedings of the Japan Academy, Series B 85 (8): 267-275.

Star, Susan Leigh, and Karen Ruhleder. 1996. "Steps Toward an Ecology of Infrastructure: Design and Access for Large Information Spaces.” Information Systems Research 7 (1): 111-134.

Stewart, Kathleen. 2011. "Atmospheric Attunements." Environment and Planning D: Society and Space 29 (3): 445-453.

Storper, Michael, and Allen J. Scott. 2016. "Current Debates in Urban Theory: A Critical Assessment.” Urban Studies 53 (6): 1114-1136.

Viveiros de Castro, Eduardo. 2014. Cannibal Metaphysics: For a Post-Structural Anthropology. Ed. and trans. Peter Skafish. Minneapolis, MN: Univocal.

Weston, Kath. 2016. Animate Planet: Making Visceral Sense of Living in a HighTech, Ecologically Damaged World. Durham, NC: Duke University Press.

Yamauchi, Akemi. 2016. “'Sanriku sekai' to shishi-odori no hajimari: Saigai to mukiau kurashi” [The origins of 'the Sanriku world' and the deer dance: Living with disaster]. Taishō Journal of Humanity and Environment 3: 53-62. 